\title{
SUSTAINABLE URBAN PLANNING IN A CROSS-BORDER CONTEXT: A CASE STUDY
}

\author{
ANNE CATHERINE GIESHOFF \& PAOLA PFENNINGER \\ Trinationaler Eurodistrict Basel, France, IBA Basel, Switzerland
}

\begin{abstract}
The trinational agglomeration of Basel is a very densely populated region attracting more and more inhabitants and employers. The use of space to provide housing and office space has become a sensitive matter in cross-border cooperation as the developments in one parts directly affects the other parts of the agglomeration. Currently, the Canton of Basel-Stadt (Switzerland) plans to delocalize its harbor and to use the harbor site for urban developments. The area borders the cities of Weil am Rhein (Germany) and Huningue (France). For this reason, the Building and Traffic Department of the Canton Basel-Stadt, the city of Weil am Rhein (Germany) and the city of Huningue (France) have defined a trinational perimeter with the aim to develop a trinational sustainable urban district: 3 Land. The project partners have developed a common set of sustainability criteria to ensure sustainability of the urban developments within the 3Land-area. It appears, however, that the notion of sustainability is defined differently in the three countries and determined by different legislations and actors in urban planning. For instance, municipalities in France may apply a particular tool for pilot projects that allows them to apply specific criteria on a site that go beyond the existing legislation. In Switzerland, foundations play in important role in fostering sustainable urban development on private property. In Germany, municipalities need to consider specific social criteria if they want to apply to national funding programs. This paper will explore the method that has been implemented in order to ensure sustainability in a cross-border context and its limitations.
\end{abstract}

Keywords: urban planning, case study, municipalities, administration, cross-border cooperation.

\section{INTRODUCTION}

The trinational agglomeration of Basel is a very densely populated and highly industrialized region. About 800,000 inhabitants live in this area [1]-[3] and about 450,000 employees work there [4]-[6]. About 120, 000 commuters cross the Swiss border on a daily basis [7]. As the region continues to attract more and more inhabitants and employees, the housing market becomes more and more dense. Since 2009 the vacancies in the city of Basel remain below $1 \%$ and the rental price index for a three-room flat has increased during the last 15 years by about 25 points [8]. Space to develop new projects is rare [9, pp. 34-35]. A current project to delocalize the harbor of Basel to the East in order to it connect directly to the railways is expected to increase the development potential of the city of Basel as this project would free up around 30 ha for urban development [10]. A 2011 study conducted by MVRDV has shown that within this area about 120 ha could be transformed to create new workplaces and housing [11, pp. 32-76]. Furthermore, the study has demonstrated that including the municipalities of Weil am Rhein (Germany) and Huningue (France) on the other side of the border would increase the development potential for each of the three cities [11, pp. 1-3]. For this reason, the cities of Basel (Switzerland), Weil am Rhein (Germany) and Huningue (France) have defined 2011 a cross-border perimeter with the (long-term) aim to develop a trinational district.

In 2012, the cities of Huningue and Weil am Rhein, the Canton (and city) of Basel, the association of collectivities Communauté de communes des trois frontiers (France) and the Departement Département du Haut-Rhin created a trinational project consortium and signed a planning agreement striving for an urban development that is "responsible towards the 
society and the environment $[\ldots]$ " $[12$, p. 3$]$. One year later, the consortium mandated the urban planning office LIN architects and urbanists to work on a masterplan for the 3Landarea that is till today called urban concept [10]. The urban concept sketches the development of the area in three domains: transportation and mobility, green and public space, and use of space, and estimates that the 3Land-area alone could attract 20,000 new inhabitants and employees [10], [13, p. 16]. Central to the urban concept is the notion of vis-à-vis: the development can only be successful if both sides of the Rhine are complementary to each other and provide a similar quality of development. A key issue for high quality development and a high quality of living is sustainability, e.g. a development that does not jeopardize natural resources or cause social or economic fractions. This is way the urban concept focuses on valorizing green space in the area, especially those along the river Rhine, extending public transport and pedestrian and cycling traffic, supplying housing for different social classes and attracting new environment-friendly and economic activities in the 3Land-area [10].

\section{SUSTAINABILITY IN URBAN PLANNING}

Economy, society and environment are tightly coupled for the better and the worse: on the one hand, economic growth means consuming natural resources and destroying the environment that provides the livelihood for our societies. On the other hand, economic growth may improve social justice by increasing public spending social services like in education, health or actions protecting the environment like wastewater treatment or waste recycling [14]. The notion of sustainability gains importance and urgency as we feel more and more the consequences of unbalanced economic growth on our environment and our society: industries pollute the air and pose severe risks to our health, rising housing prices force large number of people to leave the city centers while growing suburban areas consume more and more natural space and the biodiversity in our cities is dwindling. It thus without wonder that the European Union has declared in 2010 its intention to foster smart, sustainable and inclusive growth in cities [15].

According to Campbell, sustainable urban planning therefore means striving a balance between three conflicting goals: economic growth, social justice and protection of the environment [16]. These goals are also anchored in the planning convention 3Land [12, pp. 3-5]. For instance, the planning convention stipulates

- a responsible urban development with regard to environment and society

- mixed land use in order to avoid social segregation

- preservation of valuable habitats

- prioritization of pedestrian and cycling traffic and urban transportation environment-friendly implementation of the transformation process

However, these goals are not always understood in the same manner by the three national parts that make up the 3Land project consortium. In order to guarantee a consistent development and a high living quality the project consortium wished to apply common criteria to building projects within the 3Land-area and to the development of the whole district. Although internationally applied criteria that have been translated in labels like LEED [17] or DGBN [18] exist and pilot projects for sustainable development can be found in all three countries, it appears that these labels and experiences are not transposable to the 3Land-area as the next section will illustrate. 


\subsection{Existing sustainability labels}

The most widely applied label that certifies sustainability in the building sector is perhaps LEEDS [17] with about 92,000 participating projects in over 165 countries today [19]. Another labels called DGNB has been developed in Germany that counts to date 1224 participating projects, mostly in Germany but also in other parts of the world like Bulgaria or China [18]. Criteria focus on citizen's or stakeholder's participation and human health, energy and water consumption, life-cycle of materials or buildings and ecological aspects like preservation of habitats or space consumption. Both labels can certainly be seen as fostering a holistic notion of sustainability as defined by Campbell [16] and provide valuable help for building promoters that are committed to sustainable building methods. LEEDS and DGNB were initially set up for single buildings; DGNB, however, has more recently developed different profiles that allow to assess sustainability for whole districts, like DGNB Stadtquartiere [20]. Nevertheless, the project consortium preferred a tool flexible enough to be applied to single buildings and to the whole district which would not have been possible with the DGNB-certificate Stadtquartiere for districts as its criteria are not applicable for single buildings [21].

More flexible in this way are local pilot projects that aim to assure sustainability at different levels of a district. Lyon Confluence is one of these examples. In 2015, the city of Lyon obtained a certificate of the World Wide Fund (WWF) [22] thanks to an holistic action plan that pursues the ten principles of the WWF-initiative "one living planet" which is based on the following principles: zero Carbone emissions, zero waste, sustainable mobility, local and sustainable materials, local and sustainable grocery, sustainable water management, biodiversity, local heritage and culture, local economic development and equity, living quality [23]. In order to translate the action plan in the functional specifications for investors and building promoters, the city of Lyon used a specific planning instrument (zone d'aménagement concertée) [24] that allows the public developer to specify criteria for developments within a particular site that go beyond minimal requirements of the current legislation [25]. Even though the WWF-label has the merit of being used worldwide, it does not provide clear indicators or target values in order to monitor the success of the action plan.

A second very instructive example for pilot projects in sustainable urban planning is the project Hafencity Hamburg in Germany. Based on international initiatives like LEED and DGNB, the Hafencity Hamburg has created its own sustainability certificate (Umweltzeichen Hamburg) that covers five topics: energy efficiency, efficient use of public goods, health and living quality, use of sustainable materials and sustainable operation of buildings. With exception of the first, mandatory category, two achievement levels with precisely defined indicators for different types of buildings (flats, hotels, offices, etc.) are defined for each category. Project proposals should at least meet the minimum standard to obtain a certificate. The criteria are part of calls for proposals and tenders and therefore compulsory for promoters. The certification process of the Hafencity Hamburg is interesting as it combines international standards with precisely defined standards that are tailored to the needs of the district. Moreover, it specifies different indicators for different building types without being too complicated to apply [26]. However, in Hamburg the area was public property. This is not the case for the 3Land-area, were approximately two thirds of the land are private property [10], [27, pp. 10-11]. While criteria that go beyond the legislation are easy to apply on public sites, this may prove much more difficult if the land is private property because private partners' commitment to sustainability criteria need to be gained beforehand. Experiences from Hamburg therefore cannot be transposed as such to the 3Land-area. 
In the Canton of Basel (Switzerland), private foundations that commit themselves to sustainability play an important role in developing sustainable urban districts on private property. This is the case for instance, for the site Erlenmatt where a foundation developed a sustainability concept that is compulsory for all projects on this site [28], [29]. This concept encompasses 59 criteria covering four domains: society, economy and environment and energy. Depending on their importance for the area, criteria yield one to three points. Project proposals have to achieve at least $75 \%$ of all points in order to enter the certification process [28]. The certificate is only delivered if the building contractor can prove two years after the commissioning of the new building that criteria are met. This approach allows the developer to tailor sustainability criteria to the specific needs of a district and to emphasize certain aspects that might be particularly important for the district. Despite its merits, the process appeared to be very complicated for both, building contractors and developers. Building contractors need to be thoroughly counselled. Moreover, it has proved difficult and tedious to control target values in general and in particular those for construction work [30].

As these three examples illustrate, the underlying ideas with regard to sustainable urban development are quite similar. However, they are differently spelled out in the different countries in terms of implementation. While France provides specific planning instruments for pilot projects in urban planning, Switzerland can draw on private foundations to promote sustainable urban development. In Germany, criteria are integrated in calls for tenders and promoters need to comply with the specifications if they want the have access to these sites. Furthermore, land property and the presence of private actors like foundations that commit themselves to sustainability is an important aspect that constrains the range of possibilities that exist in order to apply sustainability criteria on a district. A cross-border project consortium like 3Land that wishes to develop a coherent and sustainable cross-border district needs thus to bridge the gap and to find a compromise that works in each of the three countries: Germany, France and Switzerland. The 3Land project consortium therefore decided to develop a project specific sustainability certificate that would work as an incentive for private developers to apply sustainability measures for projects with the $3 \mathrm{Land}$-area.

\section{A TRINATIONAL SET OF SUSTAINABILITY CRITERA}

In order to define a common sustainability certificate, the 3 Land project consortium commissioned a team of sociologies and urban planners to develop a common set of sustainability criteria [31]. This set of common criteria should enable a consistent evaluation of building projects of all types within the area and comply with the existing legal framework and urban planning instruments in the three countries. The team therefore defined a hierarchy of goals, criteria and indicators that allow for flexibility with regard to the integration of the sustainability criteria in urban planning instruments while maintaining consistent criteria within the district.

\subsection{Defining trinational sustainability criteria}

On the basis of the planning convention the team defined six main goals that apply in each country. Sustainability goals cover each of the three aspects of sustainability. For instance, goals that cover ecological aspects of criteria are to prioritize pedestrian, cycling traffic and public transport or to preserve green or open space. Economic aspects can be found in the aim to encourage an environment-friendly transformation process. Goals that reflect social aspects of sustainability are to open up areas that until are closed for the public, to foster a cooperative and participative development and to create a district for all inhabitants [31, pp. 4-6]. Goals are listed in Table 1. 
For each goal, two to four criteria have been defined (in total 14 criteria). Criteria are formulated rather broadly as it was important to find common criteria that are shared between the three countries. Each criterion is linked to two or three indicators [31, pp. 10-11]. Indicators refine the criteria. Their application can be different or even impossible depending on the urban planning legislation in the country. For instance, the criterion regarding housing in different price segments does not apply in France as the price segments are regulated by law [31, p. 5]. Moreover, indicators do not apply in the same manner to all projects. For instance, indicators that involve outdoor space only apply to projects with outdoor space. Similarly, some indicators only apply to projects with public use, buildings with mixed use, projects with several buildings or buildings with several flats. The selection of indicators depends thus also on the project type [31, pp. 6-8]. This approach makes it possible to accommodate the different situations and legal frameworks in the three countries. Concrete measures give examples on how criteria and indicators can be implemented in a project.

Table 1: Trinational goals and sustainability criteria and their descriptors.

\begin{tabular}{|c|c|c|}
\hline \multicolumn{3}{|c|}{ Trinational sustainability goals, criteria and indicators } \\
\hline Goal & Criterion & Descriptor \\
\hline \multicolumn{3}{|l|}{ Ecological aspects } \\
\hline \multirow{2}{*}{$\begin{array}{l}\text { Prioritization of } \\
\text { pedestrian, cycling } \\
\text { and public traffic }\end{array}$} & $\begin{array}{l}\text { User-friendly offers } \\
\text { for cyclist and } \\
\text { pedestrians }\end{array}$ & $\begin{array}{l}\text { Does the project contribute to connect } \\
\text { paths and streets to the external } \\
\text { network, does it contribute to densify } \\
\text { the pedestrian network? } \\
\text { Does the project contribute to create } \\
\text { user-friendly bicycle parking? }\end{array}$ \\
\hline & $\begin{array}{l}\text { Individual motorized } \\
\text { traffic that is } \\
\text { tolerable for the city }\end{array}$ & $\begin{array}{l}\text { Does the project include mobility } \\
\text { management? } \\
\text { Does the project include measures to } \\
\text { manage efficiently parking space? }\end{array}$ \\
\hline $\begin{array}{l}\text { Preservation of } \\
\text { green or open space }\end{array}$ & $\begin{array}{l}\text { Near-nature design of } \\
\text { outdoor space }\end{array}$ & $\begin{array}{l}\text { Is the outdoor space designed in a way } \\
\text { that is adapted to the climate? } \\
\text { Does the project contribute to preserve } \\
\text { or create various habitats for different } \\
\text { species? }\end{array}$ \\
\hline \multicolumn{3}{|l|}{ Economic aspects } \\
\hline $\begin{array}{l}\text { Environment- } \\
\text { friendly } \\
\text { transformation }\end{array}$ & $\begin{array}{l}\text { Use of synergies by } \\
\text { sharing } \\
\text { infrastructure, by } \\
\text { cooperating or by } \\
\text { using composite } \\
\text { systems }\end{array}$ & $\begin{array}{l}\text { Does the project include joint } \\
\text { infrastructures and projects? }\end{array}$ \\
\hline \multirow{2}{*}{$\begin{array}{l}\text { Environment- } \\
\quad \text { friendly } \\
\text { transformation }\end{array}$} & Energy efficiency & $\begin{array}{l}\text { Does the project help to reduce grey } \\
\text { energy consumption? } \\
\text { Does the project help to reduce } \\
\text { operating energy? }\end{array}$ \\
\hline & Circular economy & $\begin{array}{l}\text { Does the project allow for resource } \\
\text { saving use of materials? } \\
\text { Are components accessible? }\end{array}$ \\
\hline
\end{tabular}


Table 1: Continued.

\begin{tabular}{|c|c|c|}
\hline \multicolumn{3}{|c|}{ Trinational sustainability goals, criteria and indicators } \\
\hline Goal & Criterion & Descriptor \\
\hline \multicolumn{3}{|l|}{ Ecological aspects } \\
\hline & $\begin{array}{l}\text { Environment-friendly } \\
\text { building processes }\end{array}$ & $\begin{array}{l}\text { Does the project use environment- } \\
\text { friendly materials and building } \\
\text { materials? }\end{array}$ \\
\hline \multicolumn{3}{|l|}{ Social aspects } \\
\hline \multirow[b]{2}{*}{$\begin{array}{l}\text { Opening closed } \\
\text { areas }\end{array}$} & $\begin{array}{l}\text { Creation of public } \\
\text { space }\end{array}$ & $\begin{array}{l}\text { Does the project contribute to open } \\
\text { outdoor space to the public? } \\
\text { Does the project contribute to create a } \\
\text { network of safe and short paths? }\end{array}$ \\
\hline & $\begin{array}{l}\text { Animation of public } \\
\text { and semi-public } \\
\text { space }\end{array}$ & $\begin{array}{l}\text { Can space be used in different ways? } \\
\text { Does the project is exemplary with } \\
\text { regard to its conception? } \\
\text { Can buildings be used differently at } \\
\text { different times? }\end{array}$ \\
\hline $\begin{array}{l}\text { Cooperative and } \\
\text { participative } \\
\text { development }\end{array}$ & $\begin{array}{l}\text { Development of } \\
\text { identity and address } \\
\text { building }\end{array}$ & $\begin{array}{l}\text { Are current stakeholders and users } \\
\text { associated to the project } \\
\text { development? } \\
\text { Does the project contribute to } \\
\text { develop a new identity with new } \\
\text { offers? } \\
\text { Does the project take over existing } \\
\text { structures and elements? }\end{array}$ \\
\hline $\begin{array}{l}\text { Cooperative and } \\
\text { participative } \\
\text { development }\end{array}$ & $\begin{array}{c}\text { Participative } \\
\text { development process }\end{array}$ & $\begin{array}{l}\text { Does the project take into account } \\
\text { interests of users and operational } \\
\text { issues during its development? } \\
\text { Are citizens and stakeholders } \\
\text { involved? }\end{array}$ \\
\hline \multirow{3}{*}{$\begin{array}{l}\text { A district for all } \\
\text { inhabitants }\end{array}$} & $\begin{array}{c}\text { Diversity of property } \\
\text { owners }\end{array}$ & $\begin{array}{l}\text { Does the project allow building } \\
\text { contractors to develop projects of } \\
\text { various sizes? } \\
\text { Are different types of investors } \\
\text { active? }\end{array}$ \\
\hline & Social diversity & $\begin{array}{l}\text { Does the project include offers for } \\
\text { specific target groups? } \\
\text { Does the project include housing in } \\
\text { different price segments? } \\
\text { Does the project allow for flexibility } \\
\text { to account for different lifestyles and } \\
\text { ages? }\end{array}$ \\
\hline & $\begin{array}{l}\text { Offers and spaces } \\
\text { that serve the district }\end{array}$ & $\begin{array}{l}\text { Does the project contribute to } \\
\text { improve public offers (cafés, } \\
\text { kindergarten, etc. )? } \\
\text { Does the project contribute to create } \\
\text { meeting points? }\end{array}$ \\
\hline
\end{tabular}




\subsection{The certification process}

Interested building contractors may contact the authorities in charge. Once a building contractor has decided to apply the 3Land-criteria, a group composed by a neutral expert and urban planners representing the authorities in the three countries is set up who advices the building contractor in choosing appropriate criteria and who determines which documents or evidence has to be presented for each indicator. Evidence depends on the stage of project. During the planning phase, evidence mostly includes a concept, a draft or a report. During the realization phase, evidence can include certificates on energy consumption or the building or the construction work itself [31, pp. 10-11]. Depending on the country, criteria, indicators and evidence are laid down in a convention with the building contractor (Switzerland), implemented into competitions and public tenders (Germany) or integrated in urban planning instruments (France).

The accompanying group counsels the building contractor at each project milestone (strategical planning, test planning, tenders or competitions, preliminary project, realization) and monitors the progress. If there is a risk that indicators are not met, the accompanying group gives recommendations. Once the construction work is completed, the accompanying group evaluates definitively the project based on the evidence that has been presented and awards the 3Land-certificate if indicators are fulfilled [31, pp. 17-18].

\subsection{Implementing common sustainability criteria in three different countries: A challenging task}

Even though the sustainability criteria of the 3Land-project are in general approved by the 3Land project consortium at a technical and a political level, the implementation of the sustainability criteria proves to be difficult. One major difficulty are legal differences and different urban planning instruments in the three countries that force each project partner to follow its own procedures. This has a major impact on requirements with regard to the indicators that building contractors need to realize in order to obtain the certificate. For instance, the Canton Basel-City will lay down indicators and measures in a convention signed by the building contractor. The Canton expects that each indicator is applied, however, the building contractor may choose how to translate indicators into concrete measures. In Germany, however, the city of Weil am Rhein uses national funding programs (Städtebauförderung Soziale Stadt) that encourage social sustainability [32], and incorporates appropriate indicators in the specifications of public tenders or competitions that bind building contractors. The aim is to integrate as many indicators as possible, but not necessarily all indicators. The city of Weil am Rhein is therefore less demanding with regard to the building contractors than the canton of Basel-City. In France, criteria will be added to the local planning document. As the specifications in the local planning document are binding for the building contractor, he has to realize each criterion with at least one indicator, however, he is free to choose the indicator. As criteria are less specified than indicators, the way chosen by the City of Huningue can be considered to be the least strict one. This differences with regard to the conditions that need to be met in order to obtain the certificate certainly reduce the certificate's significance and jeopardizes a consistent development. In the long run, it cannot be excluded that development quality will suffer from these differences. Yet, it seems to be a necessary compromise in order to define any trinational sustainability criteria at all.

Another central issue is land property. As mentioned before, about two thirds of the 3 Land-area are in private property. It is therefore crucial to convince private players and 
stakeholders to apply the 3Land criteria to their development projects. It seems, however, that this aspect is linked to the reputation of the 3Land-label. The more international reputation the certificate gains the easier will it be to convince private players to participate at the certification process. Positioning the 3 Land-label at an international level requires high consistency and development quality which is put at risk by differences between countries. Learning from experiences and continuously improving the process in consequence will therefore be crucial in order to convince private land owners.

\section{OUTLOOK}

Despite the aforementioned difficulties and challenges the project consortium wishes as a next step to "test" the sustainability criteria on three pilot projects: one in each country. Each of the three pilot projects are at different stages. In the city of Weil am Rhein, the sustainability criteria are applied ex-ante to a competition on the extension of a park in order to see how well the specifications for the competition correspond to the 3Land-criteria. In the City of Huningue, criteria shall be integrated in a new zone d'aménagement concertée, an urban planning instrument that allows to lay down particular specifications for a new district. In the City of Basel, the whole certification process will be tested on a test planning. These first pilot projects will demonstrate how the process needs to be adapted in order to be an efficient and valuable tool for a coherent high quality and sustainable development of a crossborder district.

\section{REFERENCES}

[1] Statistisches Amt des Kantons Basel-Landschaft, Statistisches Jahrbuch, Muttenz, 2017.

[2] Territoire et situation géographique, Saint-Louis Agglomération, Online. https://www.agglo-saint-louis.fr/fr/saint-louis-agglomeration/territoire-situationgeographique/html. Accessed on: 6 Dec. 2017.

[3] Bundesagentur fur Arbeit Statistik, "Zahlen, Daten, Fakten: Strukturdaten und indikatoren," 6 Jun. 2017. Online. https://statistik.arbeitsagentur.de/Statistikdaten/ Detail/Aktuell/iiia4/zdf-sdi/sdi-637-0-pdf. Accessed on: 6 Dec. 2017.

[4] Statistisches Amt Basel-Stadt, Basel kompakt, 3112 2014. Online. http://www. statistik.bs.ch/haeufig-gefragt/basel-kompakt.html. Accessed on 6 Dec. 2017.

[5] L'emploi en chiffres, Saint-Louis Agglomération, 31 Dec. 2014. Online. https://www.agglo-saint-louis.fr/fr/economie-emploi-formation/tissu-economiqueterritorial/lemploi-en-chiffres/. Accessed on: 6 Dec. 2017.

[6] Statistische Ämter des Bundes und der Länder, "Erwerbstätigenrechnung," 1 Aug. 2016. Online. Available: www.statistik-portal.de/Statistik-Portal/ETR_R2B1.pdf. Accessed on: 6 Dec. 2018.

[7] PTV-Planung Transport Verkehr AG, Renforcement des transports en commun et de mobilité combinée (P\&R, B\&R) de l'Eurodistrict Trinational de Bâle, Strasbourg, 2012.

[8] Kanton Basel-Stadt, Leerstandserhebung 2017, 18 Aug. 2017. Online. file://C:/ Users/agieshoff/Downloads/2017_18_08_Slides_MK_Leerstand.pdf. Accessed on: 6 Dec. 2017.

[9] Bau-und Verkehrsdepartement des Kantons Basel-Stadt, Kantonaler Richtplan, 20 Apr. 2015. Online. http://www.richtplan.bs.ch/download/richtplan/geltenderrichtplan.html. Accessed on: 10 Apr. 2018. 
[10] LIN GmbH; Atelier Girot; Une Fabrique de la ville; IBV Hüsler; Franck Boutté; Nuesch Development; Hanimann, Joseph; Kleyer, Michael, Raumkonzept 3Land, Basel, 2015.

[11] josephy; mvrdv; cabane, 3Land Entwicklungsvision/Vision de développement, Basel, 2011.

[12] Kanton Basel-Stadt; Ville de Huningue; Communauté de Communes des Trois Frontières; Conseil Général du Haut-Rhin; Stadt Weil am Rhein, Planungsvereinbarung, Basel, 2012.

[13] LIN GmbH; Girot, Atelier; Une Fabrique de la ville; IBV Hüsler; Joseph Hanimann; Michael Kleyer; Nuesch Development, Synthèse du concept urbain / Synthese Raumkonzept 3Land, vol. V, Basel, 2015.

[14] LIN GmbH; Girot, Atelier; Une Fabrique de la ville; IBV Hüsler; Joseph Hanimann; Michael Kleyer; Nuesch Development, Synthèse du concept urbain / Synthese Raumkonzept 3Land, vol. V, Basel, 2015.

[15] European Commission, Europe 2020. A strategy for smart, sustainable and inclusive growth, Brussels, 2010.

[16] Cambell, S., Green cities, growing cities, just cities? Journal of American Planning Association, 62(13), pp. 296-312, 1996.

[17] LEED v4 for building design and construction, 5 Jan. 2018. Online. www.usgbc.org. Accessed on: 2 Mar. 2018.

[18] DGNB System, Deutsche Gesellschaft für nachhaltiges Bauen, 2 Mar. 2018. Online. http://www.dgnb-system.de/en/projects/index.php?filter_Freitextsuche=\&filter_Land $=\&$ filter_Bundesland $=\&$ filter_Standort $=\&$ filter_Jahr $=\&$ filter_Zertifizierungsart $=\&$ fil ter_Nutzungsprofil $=\&$ filter_Zertifiziert_von_ $1=\&$ filter_Verliehenes_Guetesiegel $=\& \mathrm{f}$ ilter_Archite. Accessed on: 2 Mar. 2018.

[19] LEEDS - projects, U.S. Building Council, 2018. Online. https://www.usgbc. org/projects. Accessed on: 2 Mar. 2018.

[20] Stadtquartiere (SQ), Deutsche Gesellschaft für nachhaltiges Bauen, 2016. Online. www.dgnb-system.de/de/nutzungsprofile/allenutzungsprofile/stadtquartiere.php. Accessed on: 27 Apr. 2018.

[21] Deutsche Gesellschaft für nachhaltiges Bauen, Gewichtung der Kriterien. Stadtquartiere Version 2016, 2016. Online. http://static.dgnb.de/fileadmin/de/ dgnb_system/Nutzungsprofile/Kriterienuebersicht/kriterienuebersicht-sq16.pdf?m= 1458307451\&. Accessed on: 27 Apr. 2018.

[22] WWF, 10 principes pour réinventer un quarier. Lyon Confluence, 1er quartier durable.," 2015. Online. https://www.wwf.fr/sites/default/files/doc-2017-07/15 rapport_10_principes_pour_reinventer_un_quartier_lyon_confluence.pdf. Accessed on: 9 Mar. 2018.

[23] SPL Lyon Confluence, "La Confluence, Lyon. 1er quartier durable WWF," November 2011. Online. www.lyon-confluence.fr/ressources/document/pad-ok-111206.pdf. Accessed on: 1 Mar. 2018.

[24] SPL Lyon Confluence, Un développement par étapes, SPL Lyon Confluence, 27 Apr. 2018. Online. www.lyon-confluence.fr/fr/projet-urbain/amenagement.html. Accessed on: 30 Apr. 2018.

[25] Code de l'urbanisme. Art. L311-1, France, 26 Mar. 2018. Online. www.legifrance.gouv.fr/affichCodeArticle.do?cidTexte=LEGITEXT000006074075 \&idArticle $=$ LEGIARTI000006815419\&dateTexte $=\&$ categorieLien $=$ cid. Accessed on: 30 Apr. 2018. 
[26] HafenCity Hamburg GmbH, "Umweltzeichen HafenCity. Nachhaltiges Bauen in der HafenCity. Version 3.0," 2017. Online. http://www.hafencity.com/upload/ files/artikel/Umweltzeichen_HafenCity_2017_Version_3.0_.pdf. Accessed on: 9 Mar. 2018.

[27] LIN GmbH; Girot, Atelier; Une Fabrique de la Ville; IBV Hüsler; Franck Boutté; Joseph Hanimann; Michael Kleyer; Nuesch Development, Stratégie de transformation / Strategie Transformation, vol. IV, Basel, 2015.

[28] Stiftung Habitat, Richtlinien Nachhaltigkeit für Bauherrenschaften auf Erlenmatt Ost, Basel, 2015.

[29] Die 2000-Watt-Gesellschaft als Weltformel, Fachstelle 2000-Watt-Gesellschaft, 2017 September 2017. Online. http://www.2000watt.ch/die-2000-watt-gesellschaft/. Accessed on: 9 Mar. 2018.

[30] Zimmerli, J., Personal communication, sociologist and urban planner, 2018.

[31] Zimraum and Güller Güller architecture urbanism, Trinationaler Kriterienkatalog, Basel, 2017.

[32] Programm Soziale Stadt - Städtebauförderung, Bundesministerium für Umwelt, Naturschutz, Bau und Reaktorsicherheit, Online.

www.info/StBauF/DE/Programm/SozialeStadt/Programm/programm_node.html;jses sionid=62C1CB6B047F01FD4191D209D0539D25.live11293. Accessed on: 27 Apr. 2018. 